\title{
Accumulation of Lead, Cadmium and Iron in Topsoil of Ori-lle Battery Waste Dumpsite and Surrounding Gradient Point Areas at Olodo, Ibadan, Nigeria
}

\author{
Afolayan Adedotun Onoyinka ${ }^{1,2,}$, Hassan Amusat Titilayo \\ ${ }^{1}$ Tissue Culture Section, Biotechnology Unit, National Centre for Genetic Resources and Biotechnology, Moor Plantation, Ibadan, Nigeria \\ ${ }^{2}$ Department of Zoology, University of Ibadan, Ibadan, Nigeria
}

Email address:

onoyinka@yahoo.com (Afolayan A. O.), prathassan@yahoo.co.uk (Hassan. A. T.)

${ }^{*}$ Corresponding author

To cite this article:

Afolayan Adedotun Onoyinka, Hassan Amusat Titilayo. Accumulation of Lead, Cadmium and Iron in Topsoil of Ori-Ile Battery Waste Dumpsite and Surrounding Gradient Point Areas at Olodo, Ibadan, Nigeria. International Journal of Mineral Processing and Extractive Metallurgy. Vol. 2, No. 5, 2017, pp. 68-78. doi: 10.11648/j.ijmpem.20170205.12

Received: August 25, 2017; Accepted: September 11, 2017; Published: October 23, 2017

\begin{abstract}
The disposal of waste is proving to be a major public health issue and a vital factor affecting the quality of the environment especially in the developing countries. Battery waste consists of toxic heavy metals and its incongruous disposal on the Ori-Ile battery waste dumpsite at Olodo, Ibadan has elicited public health concerns. This study was designed to determine the concentration of lead $(\mathrm{Pb})$, cadmium $(\mathrm{Cd})$ and iron $(\mathrm{Fe})$ within the topsoil of Ori-Ile battery waste dumpsite and surrounding gradient point areas at Olodo, Ibadan, Nigeria. An auto-battery Waste Dumpsite (WD), Ori-Ile, Olodo was purposively selected for the study. One hundred and thirty six (136) soil samples were collected every two months (March 2008 to July 2009) from the waste dumpsite and along the along North, South, East and West (N, S, E, W) directions at $5 \mathrm{~m}$ intervals from the edge of the wastedump site. Control soil samples were collected from Moor Plantation (MP), Ibadan. All soil samples collected were analyzed for $\mathrm{Pb}, \mathrm{Cd}$, and $\mathrm{Fe}$. Mean concentrations of $\mathrm{Pb}, \mathrm{Cd}$ and $\mathrm{Fe}$ concentration $(\mathrm{mg} / \mathrm{kg})$ in topsoil from the waste dumpsite was $\mathrm{Pb}: 4273.8 \pm 1436.7, \mathrm{Cd}: 258.4 \pm 123.1$, Fe: $7910.0 \pm 791.5$ while that from North was $\mathrm{Pb}$ :

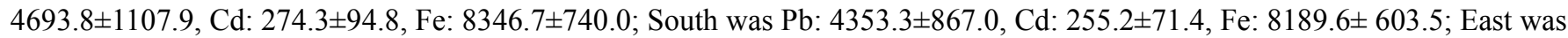

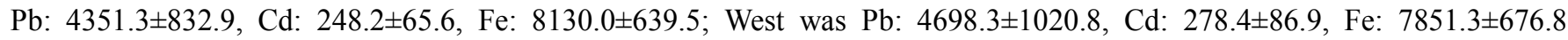
respectively. These were significantly higher than values obtained from the reference soil (157.0 $39.8,2.2 \pm 1.2,976.3 \pm 353.9$ $\mathrm{mg} / \mathrm{kg}$ respectively) and National Environmental Standard Regulation Agency (NESREA) limits (164mgPb/kg and $50 \mathrm{mgCd} / \mathrm{kg}$ ). Also, soil contamination factor values obtained were greater than 6 and this indicated severe contamination. Overall, these results have shown that the levels of $\mathrm{Pb}, \mathrm{Cd}$ and $\mathrm{Fe}$ in all sampled topsoil were several folds above the limits set by NESREA. High accumulation of heavy metals was found in the topsoil of Ori-Ile battery waste dumpsite, Olodo, Ibadan and its surroundings and this could lead to further contamination of surface water, ground water and living organisms within this polluted sites. The health of all living biota within the area could also be negatively impacted.
\end{abstract}

Keywords: Lead, Cadmium, Iron, Heavy metals, Accumulation, Contamination Factor, Battery Waste Dumpsite, Ori-Ile Olodo

\section{Introduction}

Uncontrolled open dumping on the peripheries of many cities has resulted in the degradation of valuable land resources and the creation of long-term environmental and human health problems [1]. The discharge of heavy metals as a by-product of industrial activities has been accompanied by large scale soil pollution $[2,3]$. It has been established that ineffective management of wastes could pollute soils, leading to the accumulation of toxic metals in the soils, transferred to plants and consequently into animals [4]. The nonbiodegradable materials in improperly disposed wastes are 
toxic to life in the soil, while its accumulation in soil poses a threat to plant and animal life [5]. The concern over soil pollution stems primarily from health hazards, which results from direct contact with the contaminated soil, vapours from the contaminants and from secondary contamination of water supplies within and underlying the soil [6]. Also, due to the heavy metals constituent of some wastes, environmental risk due to soil pollution is of particular importance for agricultural areas. This is because of the potential harm that such heavy metals mete out to human health [7]. Heavy metals tend to persist in the environment indefinitely [8] and get accumulated over time in soils. Excess heavy metal accumulation in soils is toxic to humans and other animals [9] and the exposure to some heavy metals in the soil can lead to health effects that cut across different gender and ages $[10,11]$. These metals when taken into the body are capable of causing serious health problems especially by interfering with the normal body functions [12]. Some of these metals like iron are useful to the body in low concentrations, but are toxic at high concentrations, while others like cadmium and lead have no biological functions and are highly toxic; disrupting bodily functions to a large extent. They disrupt bodily functions by accumulating in vital organs and glands in the human body, such as, the kidney, liver, bone, heart and brain [12]. They also displace vital nutritional minerals from their proper place in the body where they ought to provide biological functions [8]. Consequently, these metals enter the food chain in elevated amounts and affect food quality and safety; thus, posing threat to a country's food production [13]. Although, the analysis of different concentration of accumulated toxic materials within the living organisms consumed as food are issues of urgent attention, the nonliving materials within the environment is also of concern, because of their interconnection with the living environmental resources. Soil is one of such important nonliving environmental material. In cases of serious soil contamination, the entire populations of organisms, usually lower down in the food chains, which come into direct contact with the polluted soil, could be destroyed and this could in turn affect the animals higher up food chains; while in cases of less severe soil contamination, the organisms lower down the food chains may bio-accumulate the toxic substances in their bodies, and the effects of the toxins may bio-magnify in the higher animals as you go higher up the food chains [14]. This chain of pollutions most often gets toxic pollutants back to humans, which are omnivore and occupy the highest position in the food pyramid. These thus expose humans to increase concentration of pollutants especially through many feeding channels. Pollutants such as the heavy metals are significantly toxic because of their accumulative nature in the different body parts and they lead to unwanted side effects $[15,16,17]$. One other key effect of heavy metals is the ecosystem imbalance, due to its negative impact on the fauna and flora inhabiting terrestrial ecosystem [6], while other effects are associated with health hazards [5, 9]. When there is contamination of soil with toxic substances, substantial changes occur in the chemistry of the soil, which in turn affects the well-being of plants and animal life living in the soil, as well as the ecosystems that the soil supports [14].

West African Battery Industry, which used to produce the battery known as Exide Battery, between the late 1980s and the late 2000 prompted public health concerns at Olodo area, Ibadan, Nigeria; because the company used several places within the area as open dumps [18, 19]. Unfortunately, increase in population and expansion of Ibadan city in recent times resulted in the allocation of these previously used open waste dumps for housing development [18]. Ori-Ile, Ikumapaiyi area of Olodo is one of the several areas used as such open dump. This particular area is now developed and inhabited, but there was an outcall for help; based on the series of environmental challenges the inhabitants were facing. Although different studies have reported heavy metal levels of other areas in Olodo [18, 19, 20, 21, 22], this study was designed to determine the concentration of lead $(\mathrm{Pb})$, cadmium $(\mathrm{Cd})$ and iron $(\mathrm{Fe})$ within the topsoil of Ori-Ile battery waste dumpsite and surrounding gradient point areas at Olodo, Ibadan, Nigeria.

\section{Materials and Methods}

\subsection{Study Area}

The study area is a semi-urban residential and agricultural area located on latitudes $7^{\circ} 24^{\prime} 28.1^{\prime \prime} \mathrm{N}$, longitudes $4^{\circ} 00^{\prime} 52.2^{\prime \prime} \mathrm{E}$ and elevation $176 \mathrm{~m}$ respectively. It contained a waste dumpsite located at Omilende village in Ikumapaiyi Area of Olodo community, northwest of Egbeda Local Government Area, Ibadan, Oyo-State. It is popularly referred to as Ori-Ile Waste Dumpsite. Figure 1 and 2 shows the map of Ibadan with the location of the study site and the map of the study area (Olodo). The study site is a large and bare expanse of land of about 2 hectares, characterized with scanty vegetation. The most abundant group of vegetation on and around the waste dumpsite were the grasses, some of which included Panicum clandestinum (corn grass), Muhlenbergia emersleyi (bull grass) and Echinopogon ovatus (hedgehog grass). Panicum clandestinum were most abundant in areas surrounding the study site. The area has a bimodal rainfall pattern which peaks in June and September. The site was used as an unapproved waste dumpsite for battery wastes from the now closed down company called West African Battery Industry, who used to produce the battery known as 'Exide Battery'. It was also used as an informal lead recovery site by informal and local Used Lead Acid Battery operators. 

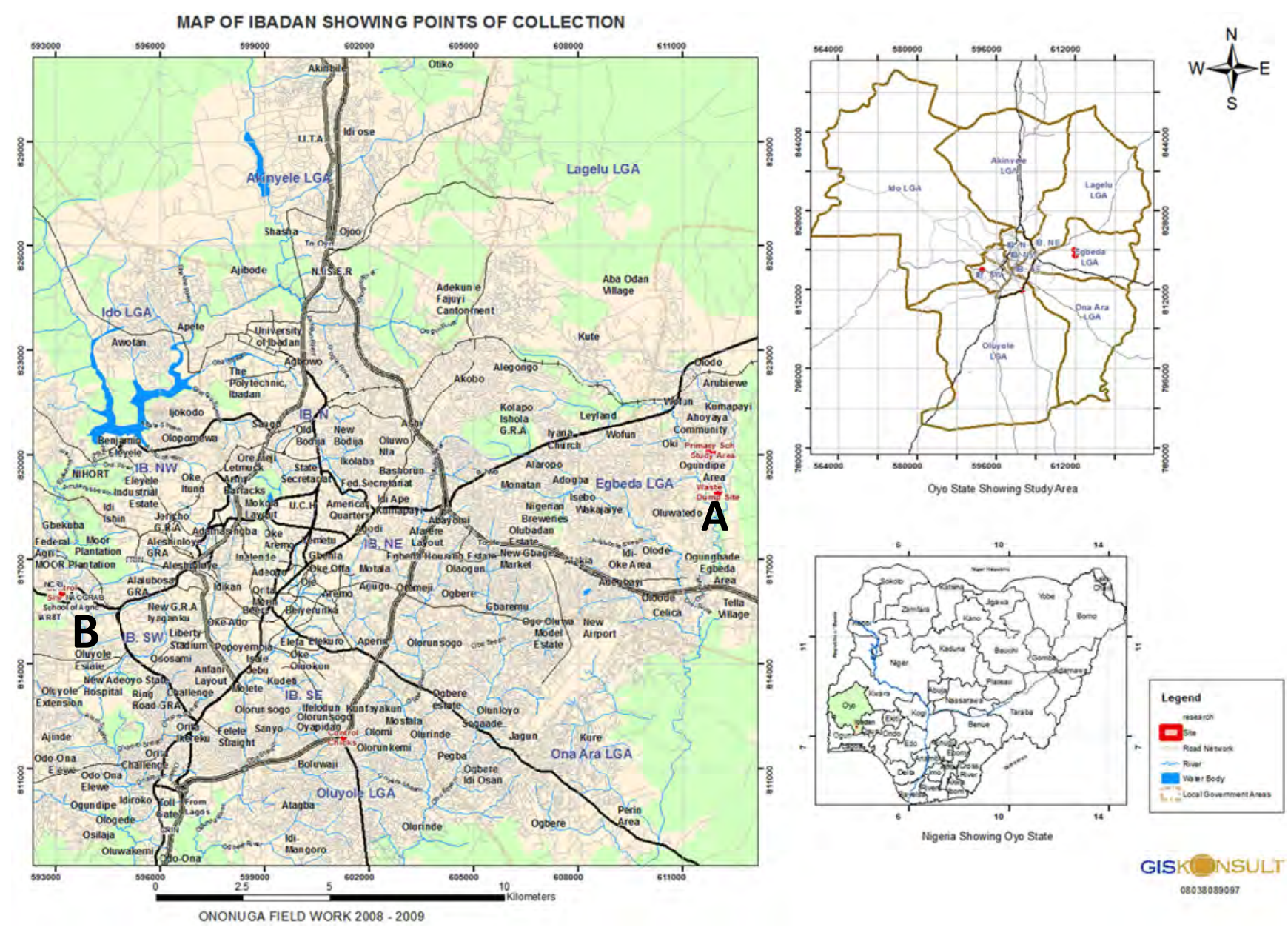

Figure 1. Map of Ibadan Showing the Ori-Ile Waste Dumpsite (A) and Reference site (B). (Source: GIS Konsult, Bodija, Ibadan).

The area surrounding the waste dumpsite is inhabited by people who are mostly peasant farmers and traders. The reference site was located at National Center for Genetic Resources and Biotechnology, Moor Plantation, Ibadan, latitude $7^{\circ} 23^{\prime} 31.5^{\prime \prime} \mathrm{N}$ and longitude $3^{\circ} 50^{\prime} 46.5^{\prime \prime} \mathrm{E}$.

\subsection{Sampling Procedure and Analysis}

\subsubsection{Soil}

One hundred and thirty six (136) top soil samples were obtained from the study site in 2008 (March, May, July and September) and 2009 (January, March, May, and July). The guidelines provided by USEPA [24] were employed during sampling. The soil samples were taken at the top region only $(0-15 \mathrm{~cm}$ deep $)$; from the waste dumpsite and along each of North, South, East and West (N, S, E and W) directions at 5 $\mathrm{m}$ intervals from the edge of the waste dumpsite. Each gradient point direction was sampled as a straight line A to $\mathrm{B}$ or $\mathrm{B}$ to $\mathrm{C}$ or $\mathrm{C}$ to $\mathrm{D}$ or $\mathrm{A}$ to $\mathrm{D}$ with a midpoint $\mathrm{M}$ and bulked together to form a composite sample (Figure 2 and 3). Geographical Positioning System (GPS) was employed in acquiring location information on specific points of sample collection during each visit (Table 1).

Table 1. GPS Data of the Soil Sampling Points of Waste Dumpsite and Reference Site.

\begin{tabular}{|c|c|c|c|c|c|c|}
\hline \multirow{2}{*}{ Gradient points } & \multirow{2}{*}{ Sampling distance } & \multirow{2}{*}{ No of samples per visit } & \multirow{2}{*}{ Sampling points } & \multicolumn{3}{|c|}{ GPS Coordinates } \\
\hline & & & & Elevation (m) & NORTH & EAST \\
\hline \multirow{8}{*}{ North } & \multirow{3}{*}{$0 \mathrm{~m}$} & \multirow{3}{*}{ One composite sample } & AN0 & 174 & 07 24' 29.3" & 00400 '52.6" \\
\hline & & & MN0 & 176 & 07 24' 28.1" & $00400^{\prime} 52.2^{\prime \prime}$ \\
\hline & & & BN00 & 172 & $0724^{\prime} 26.4^{\prime \prime}$ & $00400^{\prime} 52.0^{\prime \prime}$ \\
\hline & \multirow{2}{*}{$10 \mathrm{~m}$} & \multirow{2}{*}{ One composite sample } & AN10 & 175 & 0724 '29.4" & $00400^{\prime} 52.3^{\prime \prime}$ \\
\hline & & & $\mathrm{BN} 10$ & 176 & $0724^{\prime} 26.2^{\prime \prime}$ & $00400^{\prime} 51.6 "$ \\
\hline & \multirow{3}{*}{$20 \mathrm{~m}$} & \multirow{3}{*}{ One composite sample } & AN20 & 176 & $0724^{\prime} 29.4^{\prime \prime}$ & $00400^{\prime} 51.9^{\prime \prime}$ \\
\hline & & & MN20 & 174 & 07 24' 27.9" & $00400^{\prime} 51.6 "$ \\
\hline & & & $\mathrm{BN} 20$ & 178 & $0724^{\prime} 26.5^{\prime \prime}$ & $00400^{\prime} 51.2^{\prime \prime}$ \\
\hline
\end{tabular}




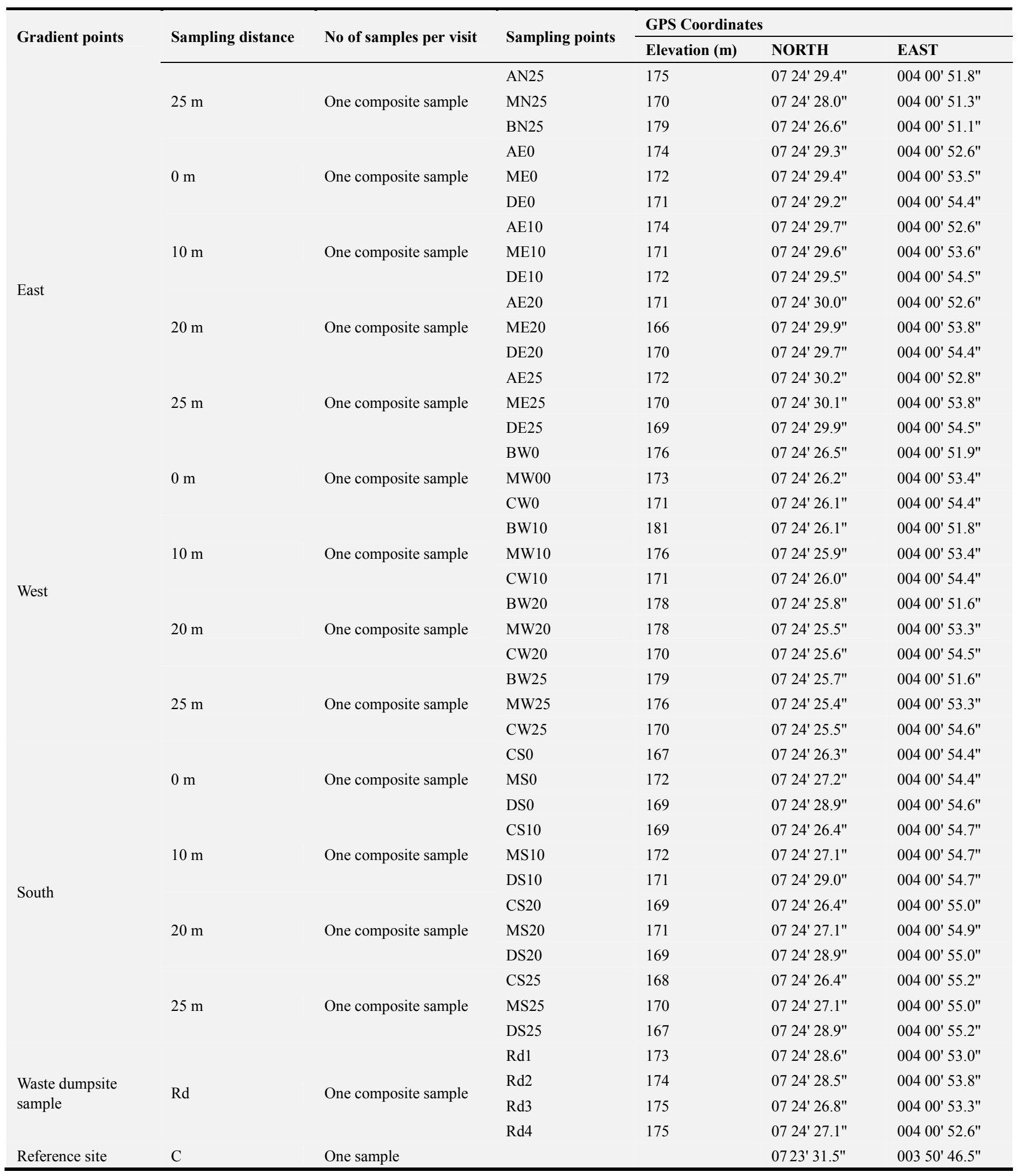

All topsoil samples were collected with the aid of a soil auger and hand trowel into clean, well-labeled polythene sampling bags. The sampling bags were sealed to prevent contamination during transportation to the laboratory and were then taken to the laboratory for processing and analysis. 


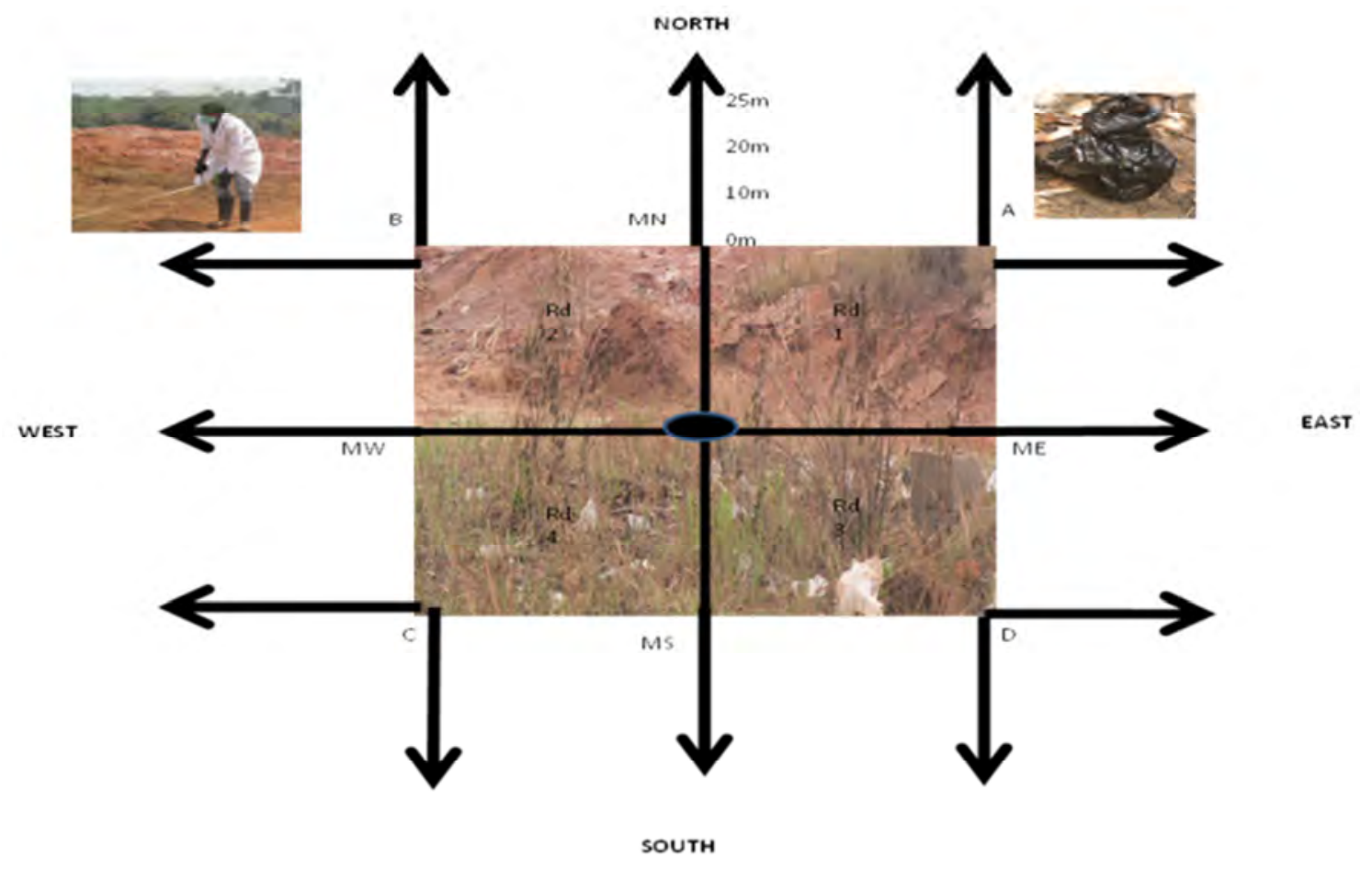

Figure 2. Schematic Diagram of Soil Sampling at Ori-Ile Waste Dumpsite.

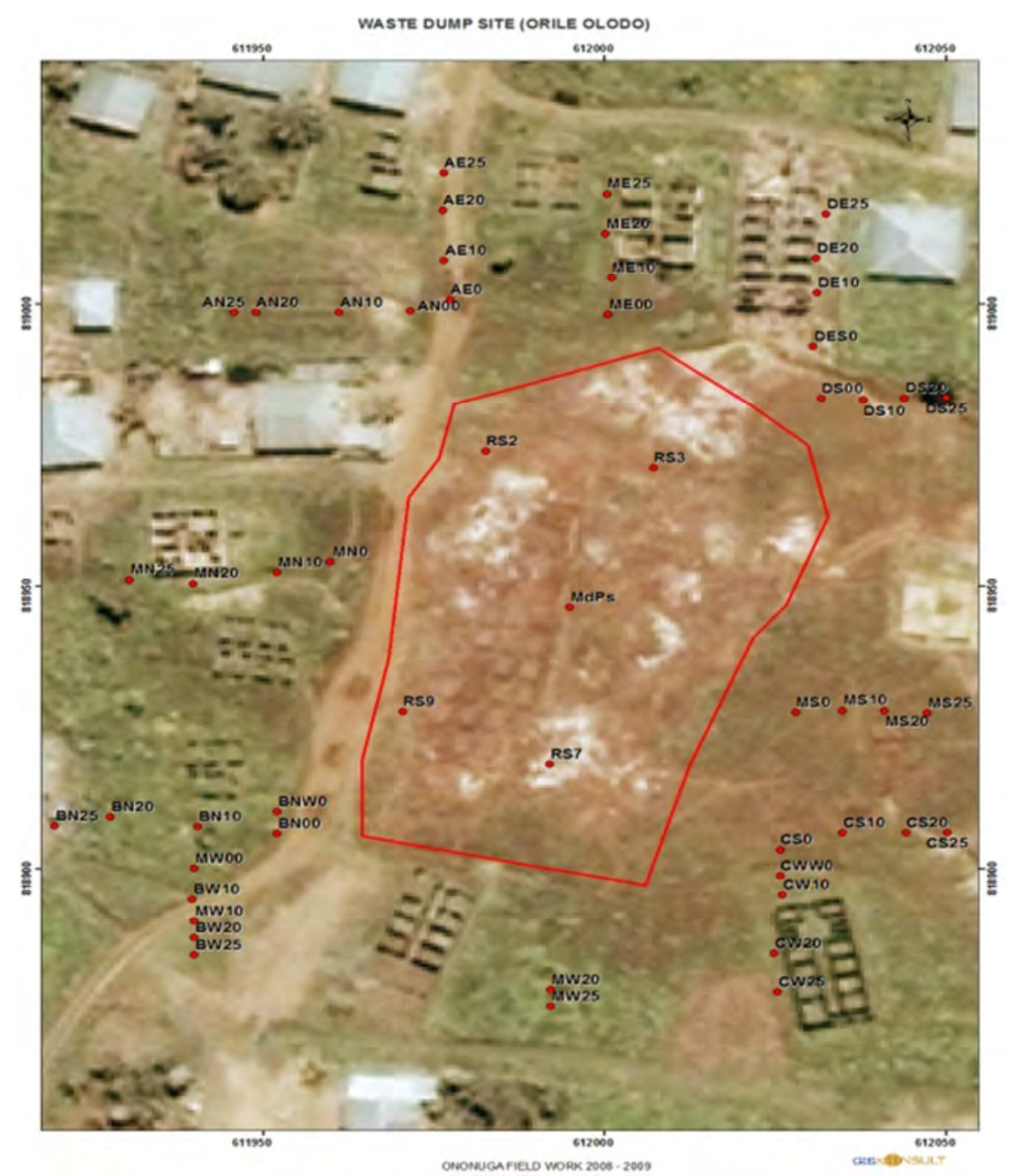

Figure 3. Satellite Image of Ori-Ile Waste Dumpsite Showing the Soil Sampling Points. 
The digestion of the samples was done according to the method adopted by Adie and Osibanjo [21]. The filtrate of the digested samples was made up to the final volume (100 $\mathrm{ml}$ ) and analysed for $\mathrm{Pb}, \mathrm{Cd}$ and $\mathrm{Fe}$ with Perkin Elmer Analyst 200 Atomic Absorption Spectrophotometer (2003 Model). The procedure was repeated for all the samples and their replicates. Reference soils were also collected and subjected to the same procedural analysis.

\subsubsection{Quality Control}

Quality control of metal analysis was performed by analysing reference samples of topsoil, and for reagents the quality assurance scheme included blank reagents.

\subsubsection{Calculated Factors}

Contamination (CF) was determined for soil using the methods adopted by Agunbiade and Fawale [25].

1. Contamination Factor (CF) is often used to access soil contamination through the comparison of the concentrations in the surface layer to the background values. It is calculated using the equation:

$\mathrm{CF}=\mathrm{C}_{(0-1)} / \mathrm{C}_{\mathrm{n}}$ (Where $\mathrm{CF}=$ contamination factor; $\mathrm{C}_{(0 \text { - }}$ 1) = mean of concentrations of individual metal from all test sites; $\mathrm{C}_{\mathrm{n}}=$ baseline or background concentration of individual $=$ concentration of metals at control site).

$\mathrm{CF}<1=$ low contamination factor

$1<\mathrm{CF}<3=$ moderate contamination factor

$3<\mathrm{CF}<6=$ considerable contamination factor

$\mathrm{CF}>6=$ very high contamination factor

2. P ollution Load Index (PLI): is used to evaluate the severity of pollution of the soils according to the definition of Tomlinson et al. [26]. It is calculated using the equation:

$$
\operatorname{PLI}=\left[\pi^{\mathrm{n}} \mathrm{i}\left(\mathrm{c}_{\mathrm{fi}}\right)\right]^{1 / \mathrm{n}}
$$

Where, Cfi is the concentration factor of each metal obtained by the ratio of concentration of each metal in soil to that of the metal in baseline soil; $\pi$ is the geometrical mean operator; $\mathrm{n}$ is the number of metals investigated and $i$ is each metal. When PLI value is below or close to one, it indicates heavy metal loads at the baseline, while values above one indicate heavy metal accumulation or pollution in soil from the test site.

\subsection{Statistical Analysis}

The results of all the heavy metals in the soil samples were grouped and analysed using factorial tool to compress the data and identify patterns of relationship within them. The results of the heavy metals in the maize parts were analysed for level of significance using the Student's T-test with a significance level of $\mathrm{p} \leq 0.05$.

\section{Results and Discussion}

\subsection{Pb, Cd and Fe Concentrations in Soil Samples}

In the topsoil samples collected from the waste dumpsite
( $\mathrm{Rd}$ sample) and its fringes $(0-25 \mathrm{~m}$ along the gradient points), a wide range of soil $\mathrm{Pb}, \mathrm{Cd}$ and $\mathrm{Fe}$ concentrations were observed and these were compared to values obtained from reference site (Table 2; Figure 4, 5 and 6). In Rd, N, E, $\mathrm{W}$ and $\mathrm{S}$ soils, $\mathrm{Pb}, \mathrm{Cd}$, and $\mathrm{Fe}$ concentrations were significantly higher $(\mathrm{p} \leq 0.05)$ compared with the reference soils $(\mathrm{C})$. The results indicated that $\mathrm{Pb}$ and $\mathrm{Cd}$ concentrations exceeded the Environmental Quality Standards set by NESREA [27] for soils in Nigeria (Table 2). However, there was significant accumulation of $\mathrm{Pb}, \mathrm{Cd}$, and $\mathrm{Fe}$ in the waste dumpsite soils and those and along each of North, South, East and West (N, S, E and $\mathrm{W})$ directions at $5 \mathrm{~m}$ intervals from the edge of the waste dumpsite compared to the reference soils. The results showed decline in mean lead and cadmium concentration along the North (N), South (S), East (E) and West (W) gradient points as the distance increases from $0 \mathrm{~m}$ to $25 \mathrm{~m}$ from the edge of the waste dumpsite (Figure 4 and 5). Overall, there was a similar pattern of lead and cadmium distribution along the distances $0 \mathrm{~m}$ to $25 \mathrm{~m}$ in each of the gradient points and it follows the order $0 \mathrm{~m}>10$ $\mathrm{m}>20 \mathrm{~m}>25 \mathrm{~m}$ (Table 2). The highest mean lead and cadmium concentration in all the gradient points was at $0 \mathrm{~m}$, which is at the edge of the waste dumpsite (Table 2). For iron however, the results showed decline in mean iron concentration along the East (E) gradient point as the distance increases from $0 \mathrm{~m}$ to $25 \mathrm{~m}$ from the edge of the waste dumpsite (Figure 6). Along the North (N) gradient point, the result revealed increase in mean iron concentration from distance $0 \mathrm{~m}$ to $10 \mathrm{~m}$ and $20 \mathrm{~m}$ to $25 \mathrm{~m}$. But, the result showed a decline from distance $10 \mathrm{~m}$ to $20 \mathrm{~m}$. Along the South (S) and West (W) gradient points, the result showed decline in mean iron concentration from distance $0 \mathrm{~m}$ to $10 \mathrm{~m}$ and $20 \mathrm{~m}$ to $25 \mathrm{~m}$; but, the result revealed an increase from distance $10 \mathrm{~m}$ to $20 \mathrm{~m}$ respectively. Overall, there was a similar pattern of iron distribution along the South (S) and West (W) gradient points only while the East and North gradient points had different pattern of iron distributions (Table 2). The highest mean iron concentration in all the gradient points was also at distance $0 \mathrm{~m}$, which is at the edge of the waste dumpsite.

\subsection{Pb, Cd and Fe Contamination Factors and Pollution Load Indices}

The CF and PLI indices respectively, using the reference soil concentrations of this study were significantly very high (Rd: $\mathrm{Pb}=27.22$ and 9.45, $\mathrm{Cd}=117.27$ and 15.38, $\mathrm{Fe}=8.10$ and $6.31 ; \mathrm{N}: \mathrm{Pb}=25.56$ and 9.26, $\mathrm{Cd}=97.18$ and 14.45, $\mathrm{Fe}=$ 7.99 and 6.28; $\mathrm{S}: \mathrm{Pb}=24.60$ and 9.14, $\mathrm{Cd}=92.64$ and 14.22, $\mathrm{Fe}=7.91$ and $6.26 ; \mathrm{W}: \mathrm{Pb}=25.35$ and $9.23, \mathrm{Cd}=98.09$ and 14.50, $\mathrm{Fe}=7.81$ and 6.24; $\mathrm{E}: \mathrm{Pb}=24.81$ and 9.16; $\mathrm{Cd}=$ 94.32 and $14.31 ; \mathrm{Fe}=8.05$ and 6.30). Overall, though all the soil CF and PLIs values were significantly very high, $\mathrm{Rd}$ topsoil had the highest CF. All the soil PLI values were above one (1) and this further indicated significant heavy metal accumulation and pollution in soil from the study site. 


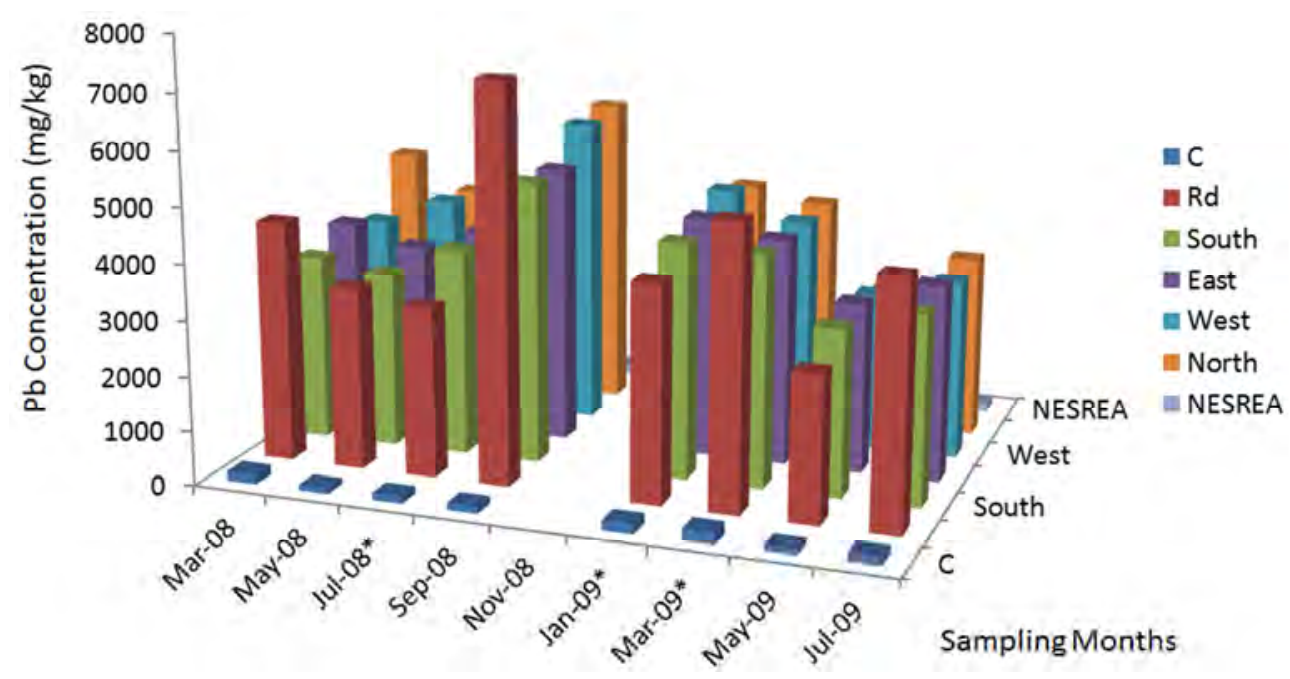

Figure 4. Mean Bimonthly Lead Concentrations in Soils of Ori-Ile Waste Dumpsite and Surrounding Gradient Points.

Key: $*$ = significant. Each bar $=$ Mean lead concentration across distance in each gradient points; successive colors $=$ collection points' lead content ( $\mathrm{C}=$ reference soil, $\mathrm{Rd}=$ waste dumpsite soil).

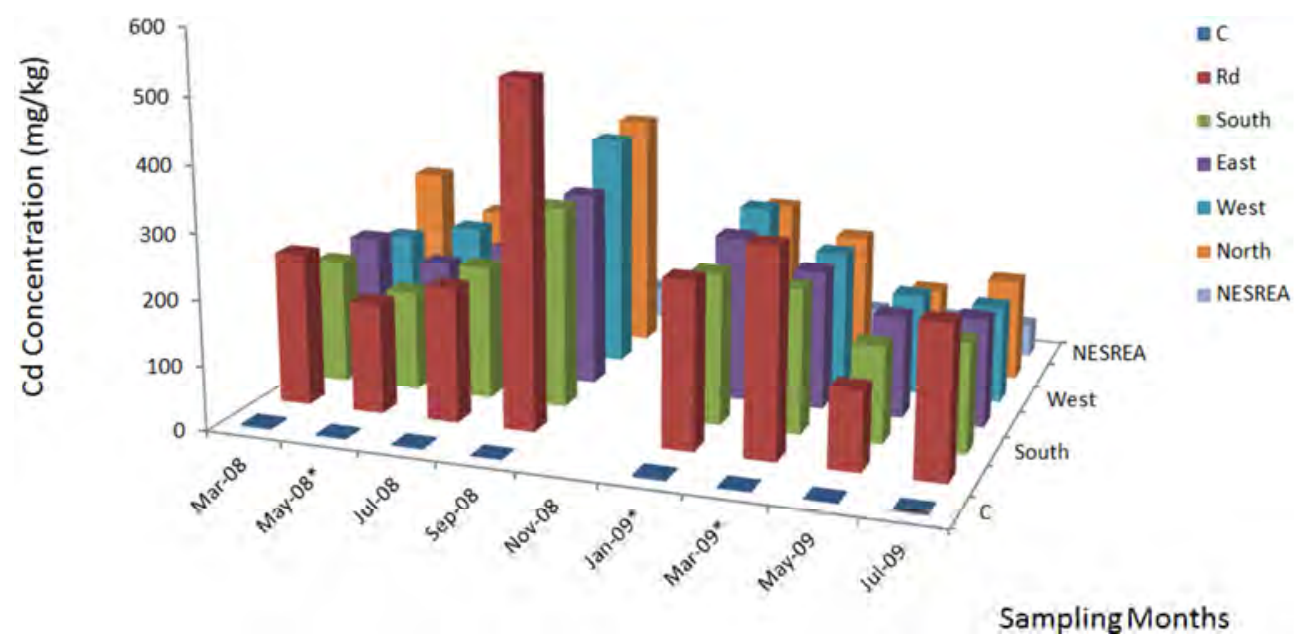

Figure 5. Mean Bimonthly Cadmium Concentrations in Soils of Ori-Ile Waste Dumpsite and Surrounding Gradient Points.

Key: * = significant. Each bar $=$ Mean cadmium concentration across distance in each gradient points; successive colors $=$ collection points' Cadmium content ( $\mathrm{C}=$ reference soil, $\mathrm{Rd}=$ waste dumpsite soil).

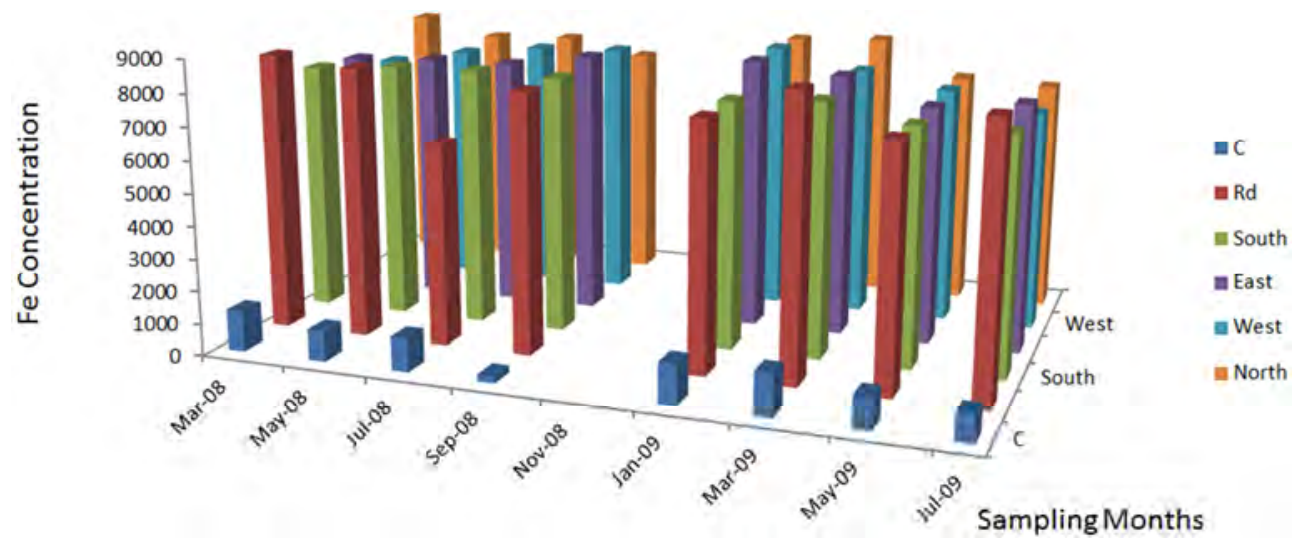

Figure 6. Mean Bimonthly Iron Concentrations in Soils of Ori-Ile Waste Dumpsite and Surrounding Gradient Points.

Key: $*$ = significant. Each bar $=$ Mean Iron concentration across distance in each gradient points; successive colors $=$ collection points' iron content $(\mathrm{C}=$ reference soil, $\mathrm{Rd}=$ waste dumpsite soil). All sampling months are not significant at $\mathrm{p} \leq 0.05$. 
Table 2. Mean Concentrations of $\mathrm{Pb}, \mathrm{Cd}$ and $\mathrm{Fe}(\mathrm{mg} / \mathrm{kg}$ ) in Soils of Waste Dumpsite (Rd) and Along Experimental Garden Direction (E).

\begin{tabular}{llll}
\hline Point X Distance & Pb (mg/kg) & $\mathbf{C d} \mathbf{( m g} / \mathbf{k g})$ & $\mathbf{F e}(\mathbf{m g} / \mathbf{k g})$ \\
\hline Rd & 4273.80 & 258.38 & 7910.00 \\
E0 & 4351.30 & 248.21 & 8130.00 \\
E10 & 4186.70 & 224.29 & 7805.41 \\
E20 & 3775.80 & 193.62 & 7769.59 \\
E25 & 3265.80 & 163.96 & 7712.90 \\
N0 & 4693.80 & 274.33 & 7840.83 \\
N10 & 4436.70 & 247.46 & 8346.68 \\
N20 & 3678.30 & 183.50 & 7443.76 \\
N25 & 3245.80 & 149.96 & 7585.40 \\
S0 & 4353.30 & 255.21 & 8189.58 \\
S10 & 4138.30 & 215.92 & 7479.18 \\
S20 & 3612.50 & 186.92 & 7765.40 \\
S25 & 3137.50 & 157.33 & 7466.24 \\
W0 & 4698.30 & 278.42 & 7851.25 \\
W10 & 4088.80 & 223.08 & 7465.84 \\
W20 & 3766.70 & 192.29 & 7666.26 \\
W25 & 3366.30 & 169.42 & 7531.25 \\
Mean & 3945.28 & 213.08 & 7762.33 \\
SD & 506.55 & 42.04 & 268.16 \\
C & 157.0 & 2.21 & 976.3 \\
NESREA & 164 & 50 & N. A. \\
\hline
\end{tabular}

This study has revealed that $\mathrm{Pb}, \mathrm{Cd}$ and $\mathrm{Fe}$ concentrations in the topsoil of the waste dumpsite (Rd) and those of distances $0 \mathrm{~m}$ to $25 \mathrm{~m}$ along its fringes in the gradient point directions from the edge of the waste dumpsite were significantly higher than the values obtained from the reference site topsoil. Also, $\mathrm{Pb}, \mathrm{Cd}$ and $\mathrm{Fe}$ concentration in the $\mathrm{Rd}$ topsoil was significantly higher than those in the distance towards $\mathrm{N}, \mathrm{S}, \mathrm{E}$ and $\mathrm{W}$; and decreased with increased distance away from $\mathrm{Rd}$. $\mathrm{Pb}$ and $\mathrm{Cd}$ concentrations obtained were several folds higher than the maximum permissible limit of $164 \mathrm{mg} / \mathrm{kg}$ and $50 \mathrm{mg} / \mathrm{kg}$ by NESREA [27].

According to Chirenje et al. [28] and Oni [1], Pb occurs naturally in all soils in concentrations ranging from 1 to 200 $\mathrm{mg} / \mathrm{kg}$ with a mean of $15 \mathrm{mg} / \mathrm{kg}$ but the values obtained in this study for Rd topsoil and those of distances $0 \mathrm{~m}$ to $25 \mathrm{~m}$ along the gradient point directions North, South, East and West from the edge of the waste dumpsite were several times beyond this range. WHO [29] reported that normal concentrations of $\mathrm{Pb}$ in soil to range from 15 to $30 \mathrm{mg} / \mathrm{kg}$ but this study $\mathrm{Pb}$ values were much higher than this value. $\mathrm{Pb}$ concentrations obtained were at very high concentrations than the maximum tolerable levels proposed for agricultural

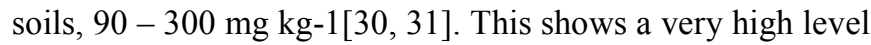
of $\mathrm{Pb}$ contamination of the topsoil of the study site. Onianwa and Fakayode [32], in their study on lead contamination of topsoil in the vicinity of a battery factory in Nigeria, reported the mean lead level of $50-2000 \mathrm{mg} / \mathrm{kg}$ in the topsoil studied. However, this study $\mathrm{Pb}$ values exceeded this range reported. In the study of Adie and Osibanjo's [21] on soil polluted by slag from an automobile battery manufacturing plant in Nigeria, a range of $243-126000 \mathrm{mg} / \mathrm{kg}$ was reported for $\mathrm{Pb}$ concentration. The mean values obtained in all the samples on and within the vicinity of the dumpsite were within this range and thus compare significantly with the result reported. The range of $419.54-10630.04 \mathrm{mg} / \mathrm{kg}$ was reported in the studies conducted by Oyediran and Aladejana [18] on impact assessment and safety status of the excavated waste site at Olodo, Ibadan, Nigeria. This also corroborates the values obtained in this study.

WHO [33] reported that the median Cd concentration in soil of areas not known to be polluted ranges from $0.2-0.4$ $\mathrm{mg} / \mathrm{kg}$. The cadmium concentrations obtained in this study were far higher than these stated values. The range of $1.95-$ $32.83 \mathrm{mg} / \mathrm{kg}$ obtained by Oyediran and Aladejana [18] in their studies on battery waste polluted areas was much less than the values obtained for $\mathrm{Cd}$ concentration in this study.

According to Eddy et al [34], the background level of Fe in natural soils was stated to range widely between 3,000 $500,000 \mathrm{mg} / \mathrm{kg}$ on elemental composition of soil in some dumpsites in Nigeria. The values obtained for soil iron concentrations in this study falls within the range reported by Eddy et al [34] as the background level of iron in natural soils. Oyediran and Aladejana [18] reported the range of $32900.08 \mathrm{mg} / \mathrm{kg}-71250.17 \mathrm{mg} / \mathrm{kg}$ for Fe concentrations in their studies on battery waste polluted areas. The Fe concentrations obtained in this study were several folds lower than those reported.

All soil contamination factors $(\mathrm{CF}>6)$ and pollution load indices (PLI $>1$ ) were significantly high. This confirmed high pollution of the topsoil of the waste dumpsite and those of distances $0 \mathrm{~m}$ to $25 \mathrm{~m}$ along the gradient point directions North, South, East and West from the edge of the waste dumpsite. From the contamination factor and pollution load index values obtained, $\mathrm{Cd}$ was the highest contaminant in all the top-soils sampled at the study site, followed by $\mathrm{Pb}$ and Fe. The CF and PLI values for samples collected from the waste dumpsite for $\mathrm{Pb}, \mathrm{Cd}$ and $\mathrm{Fe}$ indicated that the topsoil on the waste dumpsite had the highest pollution for $\mathrm{Pb}, \mathrm{Cd}$ and $\mathrm{Fe}$, followed by the topsoil along the gradient point directions in the order North, West, East and South for $\mathrm{Pb}$ and East, North, South and West for iron. The contamination 
of the soil with iron is not much of a concern if not ingested, since iron is among the required beneficial metals to plants and animals, though absorption of very high concentration without immediate utilization in the body could lead to toxicity. However, cadmium and lead are of serious concern and adequate control of their sources is paramount because of their negative impact on biota and the ecosystem at large.

The input of heavy metals to soil from various sources may prove detrimental to the supported primary producers, especially through uptake beyond toxic limit and this may facilitate their entry into the food chain. Consequently, the resultant effect of exposure to these metals may be detrimental to the well-being of both the producers and chain of consumers that such soil supports due to their capacity to affect deleteriously the biota activities: its growth, health, life span and reproduction performance [35]. According to Mohammed et al [36], working in or living near industrial sites which utilize these metals and their compounds increases environmental risks, as does living near sites where these metals have been improperly disposed.

Table 3. Correlation Between Pb, Cd and Fe in Ori-Ile Waste-dump Soil and Surroundings in March-September, 2008 and January -July, 2009.

\begin{tabular}{|c|c|c|c|c|c|c|c|c|c|c|c|c|}
\hline \multirow[b]{2}{*}{ Metals } & \multicolumn{2}{|c|}{ March 2008} & \multicolumn{3}{|c|}{ May 2008} & \multicolumn{3}{|c|}{ July 2008} & \multicolumn{3}{|c|}{ September 2008} & \multirow[b]{2}{*}{$\mathbf{F e}$} \\
\hline & $\mathbf{P b}$ & Cd & $\mathbf{F e}$ & $\mathbf{P b}$ & Cd & $\mathbf{F e}$ & $\mathbf{P b}$ & Cd & $\mathbf{F e}$ & $\mathbf{P b}$ & Cd & \\
\hline $\mathrm{Pb}$ & 1 & & & 1 & & & 1 & & & 1 & & \\
\hline $\mathrm{Cd}$ & $0.9690 *$ & 1 & & $0.9709 *$ & 1 & & $0.9029 *$ & 1 & & $0.9762 *$ & 1 & \\
\hline $\mathrm{Fe}$ & $0.8216^{*}$ & $0.7614 *$ & 1 & $0.8382^{*}$ & $0.7816^{*}$ & 1 & $0.8797 *$ & $0.7392 *$ & 1 & $0.8345^{*}$ & $0.7216^{*}$ & 1 \\
\hline
\end{tabular}

\begin{tabular}{|c|c|c|c|c|c|c|c|c|c|c|c|c|}
\hline & January & & & March 2 & & & May 200 & & & July 200 & & \\
\hline Metals & $\mathbf{P b}$ & Cd & $\mathrm{Fe}$ & $\mathbf{P b}$ & Cd & $\mathbf{F e}$ & $\mathbf{P b}$ & Cd & $\mathbf{F e}$ & $\mathbf{P b}$ & Cd & $\mathrm{Fe}$ \\
\hline $\mathrm{Pb}$ & 1 & & & 1 & & & 1 & & & 1 & & \\
\hline $\mathrm{Cd}$ & $0.9688^{*}$ & 1 & & $0.9653 *$ & 1 & & $0.9220 *$ & 1 & & $0.9770^{*}$ & 1 & \\
\hline $\mathrm{Fe}$ & $0.8651^{*}$ & $0.7781^{*}$ & 1 & $0.9290 *$ & $0.8408^{*}$ & 1 & $0.8086^{*}$ & $0.8241 *$ & 1 & $0.8699 *$ & $0.8328 *$ & 1 \\
\hline
\end{tabular}

$\mathrm{N}=136$ (Values with $*$ are significant at $\mathrm{P}<0.05$ ).

\subsection{Correlation between Pb, Cd and Fe in Topsoil Samples}

The result of the determination of the correlation coefficient of the values obtained for lead, cadmium and iron in the topsoil samples of the waste dumpsite and those of distance $0 \mathrm{~m}-25 \mathrm{~m}$ along the gradient points directions around the waste dumpsite indicated that there was a significant inter-correlation at confidence limit $\mathrm{p} \leq 0.05$ (Table 3). Oni [1], Rieuwerts et al [37] and Navas and Machin [38] stated that most soil elements showed significant intercorrelations. The findings of this study agree with this statement. For all of the period of sampling, there was a significant positive inter-correlation between lead and cadmium and between lead and iron at $\mathrm{p} \leq 0.05$, each of which were above 0.6 respectively. Also, there was a significant positive inter-correlation which were above 0.6 , between cadmium and each of lead and iron at $p \leq 0.05$. Iron also showed positive and significant inter-correlation with lead and cadmium respectively (Table 3). Therefore, there suggests that the increase in concentration of any one of the metals will cause a corresponding increase in the concentration of the other two. Also, it implies that the presence of the three metals in super-abundant concentration indicated that the wastes discarded on the waste dumpsite consisted of the three analyzed heavy metals in an interrelational measure such that the presence of higher concentration of lead could also be the reason why cadmium and iron were found in considerable high concentrations as well. As such, these three metals are somehow part of the components of the battery waste. Hence, monitoring and evaluation of heavy metal concentration in soils, water and other related environment is essential so as to identify hazards to human health and prevent bioaccumulation in the food chain or further degradation of the ecosystem [39, 40,
41]. According to Ite et al $[39,40]$, this is further necessary because activities that ensure continuous evaluation of heavy metals concentrations in the environment contribute towards effective understanding and assessment of the ecosystem health; since a healthy ecosystem will lead to a sustainable and productive agro-economy.

\section{Conclusion}

The results obtained in this study has shown that the topsoil samples taken from the waste dumpsite and its surrounding gradient points using predefined sampling points, contained very high and toxic level of lead, cadmium and iron. Apart from this, from cursory observations, the waste dumpsite area was bare having scanty vegetation, despite the fact that the surrounding areas were furnished with diverse arrays of plants. The concentration of lead, cadmium and iron in the topsoil along the North, South, East and West directions at $5 \mathrm{~m}$ intervals from the edge of the waste dumpsite were very high. This may be due to the fact that all these areas were also used as open waste dumpsite before the present study was conducted. It could also be due to the spread of the battery waste components to the other parts of the Ori-Ile Olodo community through the dispersal agents such as wind and water erosion or even residents including children. Battery cases were seen within the vicinity of the residents' homes that were being used for different domestic activities. This was also confirmed by Adie and Osibanjo [21]; Iwegbue et al. [42]; Chen et al. [43] and Oyediran and Aladejana, [18]. Therefore, continuous exposure to the very high concentrations of the studied heavy metals from battery wastes, as found in this study result, would be dangerous to thehealth of all living organisms 
around Ori-Ile battery waste dumpsite and especially the human residents' health. Therefore, intensive remediation and decontamination measure should be carried out beyond the waste dumpsite up to about $2 \mathrm{~km}$ distance, to avoid any outbreak of diseases in the near future because the area is occupied by ignorant residents who have no knowledge of the extent of the effect of the battery waste on their health.

\section{References}

[1] Oni, A. A., 2010. Physico-chemical parameters and toxicity of solid waste and leachates on selected animals at Aba-Eku landfill site, Ibadan, Nigeria. Ph.D. Thesis. Department of Zoology, University of Ibadan. 330p.

[2] Kumar, D., Rai, J. and Gaur, J. P., 2012. Removal of metal ions by Phormidium bigranulatum (Cyanobacteria)-dominated mat in batch and continuous flow systems. Bioresour. Technol., 104 (2012), pp. 202-207.

[3] Shivhare L. and Sharma S (2012). Effects of toxic heavy metal contaminated soil on an ornamental plant Georgina wild (Dahlia). Environ Anal Toxicol 2.

[4] Swarup, D., Patra R. C., Naresh R., Kumar P., Shekhar P. and Baragangatharathilagar M., 2006. Lowered blood copper and cobalt contents in goats reared around lead-zinc smelter. Small Ruminant Res., 63: 309-313.

[5] Manali, O. 2010. Facts about land pollution. (C2000-2009, 2010 Buzzle.com ${ }^{\circledR}$. Retrieved from:

www.buzzle.com/articles/facts-about-land-pollution.html

[6] United States Environmental Protection Agency (U.S. EPA), 2011. Integrated Risk Information System: Copper (CASRN 7440-50-8). Copper and cancer. Accessed March 11, 2011.

[7] Mwegoha, W. and Kihampa, C., 2010. Heavy Metal Contamination in Agricultural Soils and Water in Dar es Salaam City, Tanzania. African Journal of Environmental Science and Technology, Vol 4 (11) pp 763-769.

[8] European Union, 2002. Heavy Metals in Wastes, European Commission on Environment

(http://ec.europa.eu/environment/waste/studies/pdf/heavy_met alsreport.pdf)

[9] United States Department of Agriculture, (USDA), 2000. Heavy Metals Contamination, Soil Quality Urban Technical Note 3, Natural Resources Conservation Service

[10] Agusa, T., Kunito, T., Fujihara, J., Kubota, R., Minh, T. B., Trang, P. T. K., Iwata, H., Subramanin, A., Viet, O. H. and Tanabe S., 2006. Contamination by Arsenic and other trace elements in tube-well water and its risk assessment to humans in Hanoi, Vietnam. Environ. Poll. 139, 95-106.

[11] Needleman, H. L., Schell, A., Bellinger, D., Leviton, A. and Allred, E. N., 1990. The long-term effects of exposure to low doses of lead in childhood: an 11 year followup report. $N$. Engl. J. Med. 32, 83-88.

[12] Kumar, D., Rai, J. and Gaur, J. P., 2012. Removal of metal ions by Phormidium bigranulatum (Cyanobacteria)-dominated mat in batch and continuous flow systems. Bioresour. Technol., 104 (2012), pp. 202-207.

[13] Alloway, B. J., 2004. Zinc in Soils and Crop Nutrition.
International Zinc Association, Brussels. 130pp. Available at www.zinc-crops.org

[14] All Recycling Facts, 2012. Type of Pollution on land. In: allrecycling-facts.com. Copyright $2009-2014$.

[15] Järup, L., 2003. Hazards of heavy metal contamination, Brit. Med. Bull., 68: 167-182.

[16] Sathawara, N. G., Parikh, D. J., and Agarwal, Y. K., 2004. Essential heavy metals in environmental samples from western India. Bul. Environ. Contam. Toxicol., 73: 756 -761.

[17] Yusuf, A. A., Arowolo T. A. and Bamgbose O., 2003. Cadmium, copper and nickel levels in vegetables from industrial and residential areas of Lagos City, Nigeria. Food Chem. Toxicol., 41: 375-378.

[18] Oyediran, I. A. and Aladejana, J. A., 2011. Assessment of Impact and Safety Status of Remediation of Lead Contaminated Soil using Excavation Method: A Case Study of Olodo, Ibadan, Southwestern Nigeria. Proceedings of the Environmental Management Conference, Federal University of Agriculture, Abeokuta, Nigeria.

[19] Adeagbo, O. A., 2011. Impact of waste batteries dumpsite on the water quality of parts of Ibadan northeast (sheet 261), southwestern Nigeria. Global journal of pure and applied sciences 17: 2 .

[20] Olusoga, T. O. and Osibanjo, O. O., 2007. Contamination of soil with battery wastes: prospect for phytoremediation. European Journal of Scientific Research 17. 1: 6-10.

[21] Adie, G. U. and Osibanjo, O., 2009. Assessment of SoilPollution by Slag from an Automobile Battery Manufacturing Plant in Nigeria. African Journal of Environmental Science and Technology 3 (9): 239-250.

[22] Sridhar, S., Botbol, Y., Macian, F. and Cuervo, A. M., 2012. Autophagy and Disease: Always Two Sides to a Problem. $J$ Pathol. 226(2): 255-273

[23] GIS Konsult (Geography Information System), 2012. Map informations and Geographical Mapping. Opposite Awolowo Junction, Bodija, Ibadan.

[24] United States Environmental Protection Agency (USEPA), 2000. Data Quality Objectives Process for Hazardous Waste Site Investigations. EPA QA/G-4HW Final. Office of Environmental Information Washington, DC 20460.

[25] Agunbiade, F. O. and Fawale, A. T., 2009. Use of Siam Weed Biomarker in Assessing Heavy Metal Contamination in Traffic and Solid Waste Polluted Areas. International Journal of Environmental Science and Technology 6 (2): 267-276.

[26] Tomlinson D. L., Wilson, J. G., Harris C. R. and Jeffrey D. W. 1980. Problems in Assessment of Heavy Metals in Estuaries and the Formation of Pollution Index. Helgoland Marine Research · March 1980. (10) 1007.

[27] National Environmental Standards and Regulations Enforcement Agency. (NESREA), 2011. National Environmental (Surface and Groundwater quality) Regulations. S. I. 22.

[28] Chirenje, T., Ma, L., Reeves, M. and Szulczewski, M., 2004. Lead distribution in near-surface soils of two Florida cities: Gainesville and Miami. Geoderma 119: 113-120. 
[29] World Health Organization, (WHO), 1989. Heavy metals environmental aspects. Environment Health Criteria. No. 85. Geneva, Switzerland.

[30] Kabata-Pendias A. and Pendias, H. K., 1984. Trace Elements in soils and Plants. $2^{\text {nd }}$ edition. CRC Press, Boca Raton Ann Arbor. $10-20 \mathrm{p}, 45-78 \mathrm{p}$.

[31] Atayese, M. O., A. I. Eigbadon, K. A. Oluwa and J. K. Adeosun, 2008. Heavy metal contamination of Amaranthus grown along major highways in Lagos, Nigeria. Afr. Crop Sci. J., 16: 225-235.

[32] Onianwa, P. C. and Fakayode, S. O., 2000. Lead contamination of topsoil and vegetation in the vicinity of a battery factory in Nigeria. Environmental Geochemistry and Health 22.3: 211-218.

[33] World Health Organization, (WHO), 1992. Cadmium. International programme on chemical safety. Environmental Health criteria 134: 13.

[34] Eddy, N. O., Odoemelem, S. A. and Mbaba, A., 2006. Elemental compositions of soil in some dump sites. Journal of environmental, agricultural and food chemistry 5.3: 13491365 .

[35] Sleshi Fentie Tadesse, Worku Lakew Kebede. Determination of the Level of Selected Heavy Metals from Khat Leaves (Cata Edulis Forsk) Grown in Gidolle Konso and Koyira, Southern Ethiopia. Science Journal of Analytical Chemistry. Vol. 3, No. 6, 2015, pp. 115-121. doi: 10.11648/j.sjac.20150306.16.

[36] Mohamed Ezeldin, Sulieman A. G. Nasir, Ali M. Masaad, Nawal M. Suleman. Determination of Some Heavy Metals in Raw Petroleum Wastewater Samples Before and After Passing on Australis Phragmites Plant. American Journal of Environmental Protection. Vol. 4, No. 6, 2015, pp. 354-357. doi: $10.11648 /$ j.ajep.20150406.22.

[37] Rieuwerts, J. S., Ashnore, M. R. and Farago, M. E. and
Thornton, I., 2006. The influence of soil characteristics on the extractability of $\mathrm{Cd}, \mathrm{Pb}$ and $\mathrm{Zn}$ in upland and moorland soils. Sci. Total Environ., 366, 864-875.

[38] Navas, A. and Machin, J., 2002. Spatial distribution of heavy metals and arsenic in soils of aragon (North-East spain): controlling factors and environmental implications. Applied geochemistry 17: 961-973.

[39] Sadiq Abdurrahman Abubakar Shawai, Halima Ibrahim Muktar, Ado Garba Bataiya, Idris Imam Abdullahi, Ibrahim Muhammad Shamsuddin, Abba Shehu Yahaya, Maimua Suleiman, A Review on Heavy Metals Contamination in Water and Soil: Effects, Sources and Phytoremediation Techniques, International Journal of Mineral Processing and Extractive Metallurgy. Vol. 2, No. 2, 2017, pp. 21-27. doi: 10.11648/j.ijmpem.20170202.12.

[40] Ite, A. E., I. I. Udusoro, and U. J. Ibok, "Distribution of some Atmospheric Heavy metals in Lichen and Moss samples collected from Eket and Ibeno Local government Areas of Akwa Ibom State, Nigeria." American journal of Environmental protection, 2(1). 22-31, 2014.

[41] Etesin, U. M., A. E. Ite, T. A. Harry, C. E. Bassey, and E. W. Nsi, "Assessment of cadmium and lead distribution in the outcrop Rocks of Abakaliki Anticlinorium in the southern Benue Trough, Nigeria”. Journal of Environmental pollution and Human Health, 3(3). 62-69. 2015.

[42] Iwegbue, C. M. A., Egobueze, F. E. and Opuene, K., 2006. Preliminary assessment of heavy metals levels of soils of an oil field in the Niger Delta, Nig., Int. J. Environ. Sci. Tech. 3(2): $167-172$.

[43] Chen, T., Liu, X., Li, X., Zhao, K., Zhang, J., Xu, J., Shi, J. and Dahlgren, R. A., 2009. Heavy metal sources identification and sampling uncertainty analysis in a field-scale vegetable soil of Hang Zhou, China. Environ. Pollution, 157: 10031010 . 